\title{
Effect of multi-layer prosthetic foam liner on the stresses at the stump-prosthetic interface
}

\author{
I. Boudjemaa, A. Sahli, A. Benkhettou, S. Benbarek \\ Department of Mechanical Engineering, Laboratory Mechanics Physics of Materials (LMPM), University of SidiBel Abbes, BP \\ 89, cite Ben M'bidi, SidiBel Abbes, 22000, Algeria \\ ismailboubou000@gmail.com \\ sabliabderabmen@yahoo.fr,http://orcid.org/0000-0002-5183-1168 \\ aekben.d₹@22gmail.com \\ sma_benbarek@yahoo.fr, bttp://orcid.org/0000-0002-5420-9144
}

\begin{abstract}
The prosthetic liner plays a significant role in the redistribution of the pressure between the stump and the socket, as adds a cushioning layer between the stump and the socket which relieves pain and makes the prosthesis more comfortable.

This study employed nonlinear finite element analyses to investigate the peak pressure and shear stress at stump-prosthetic interface in the case of multilayer prosthetic foam liner, this liner has an inner polymeric foam layer Surrounded by another type of polymeric foam layer, we used three different types of foams in different order to define this liner (flexible polyurethane foam, polyurethane-shape memory polymer foam, and natural rubber latex foam). That allows comparing 6 deferent configurations of multi-layer prosthetic foam liner.
\end{abstract}

KeYwords. Prosthesis; Stump; Contacts stresses; Multi-layer liner; Transtibial amputation.

\section{OPEN ACCESS}

Citation: Boudjemaa, I., Sahli, A., Benkhettou, A., Benbarek, S., Effect of multilayer prosthetic foam liner on the stresses at the stump-prosthetic interface, Frattura ed Integrità Strutturale, 56 (2021) 187-194.

Received: 25.02 .2021

Accepted: 18.03 .2021 Published: 01.04.2021

Copyright: (C) 2021 This is an open access article under the terms of the CC-BY 4.0, which permits unrestricted use, distribution, and reproduction in any medium, provided the original author and source are credited.

\section{INTRODUCTION}

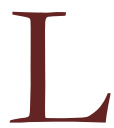

ower limb amputations are mainly due to arterial disease problems, often associated with diabetes, and to a lesser extent to trauma and cancer [1], after trans-tibial amputation (TTA) patients need prostheses to keep their mobility, this prosthesis should be comfortable and should not cause pain to the patient. Lower limb prostheses are generally developed with three principal parts: socket, pylon (leg section), and foot [2], most modern sockets are used with an intermediate liner, this liner helps to redistribute the stresses at the stump-prosthetic interface [3], the contact pressure at the stump-prosthetic interface is the most important parameter to evaluate the comfort of the prosthesis.

Sockets are customer products, designed to fit the unique geometry of the patient's residual limb [2]. Significant trauma can be caused by a poorly fitting socket. The manufacturing process of a socket is based on patient feedback and the 
personal judgment of the prosthetics. This process is long and expensive requiring several prototypes to arrive at the final product. These lead to the high prices of the products [4], and they are built to withstand only three to five years.

A low-cost efficient socket design and manufacturing process are required in order to reduce the high price of these products.

There are many advantages in using finite element analysis (FEA), including the ability to determine the stresses distribution at the whole stump-prosthetic interface. Also, these results can be used to design high-performance prosthesis by reducing the contact stresses, several studies have used the element finite method to investigate the pressures at the stump-prosthetic interface, and some model in these studies didn't include a prosthetic liner $[4,5]$, while others included liner. Lin et al (2004) [3] studied the Effects of liner stiffness in trans-tibial model, they used an axial load of $600 \mathrm{~N}$ (oneleg stance) with linear material properties for all components (bone, soft tissue, liner, socket). Jia et al (2004) [6]studied the influence of inertial load on interface pressure and shear stress in this study a prosthetic liner with $4 \mathrm{~mm}$ thickness has been used with patellar tendon bearing socket. Cagle et al (2018) [7] investigate the pressure distribution at the stump-prosthetic interface in three different limb shapes (short conical, long conical, and cylindrical) and they used elastomeric liner, the peak contact pressure across all simulations was $98 \mathrm{Kpa}$ and the maximum resultant shear stress was $50 \mathrm{Kpa}$ in Cagle's study.

In this study a trans-tibial element finite model was developed to investigate the effect of the multi-layer prosthetic foam liner on the stresses at the stump-prosthetic interface, this liner has an inner polymeric foam layer Surrounded by another type of polymeric foam layer, three different polymeric foams were chosen (flexible polyurethane foam, polyurethaneshape memory polymer foam, and natural rubber latex foam) to get different combinations of liners.

\section{METHOD}

Geometries

7 he development of the finite element (FE) model in this study was passed through several stages, the first was to create a 3D trans-tibial model with liner and socket, the limb was generated from Computed Tomography scans, the socket and the liner was designed using Autodesk meshmixer, this software allows to adapt the liner shape and socket with the residual limp and also allows to get rid of cavities in the contact surface between the residual limb and the liner and between the liner and the socket (Fig. 1), the model has been converted from STL to IGS with MIMICS 3MATIC software.
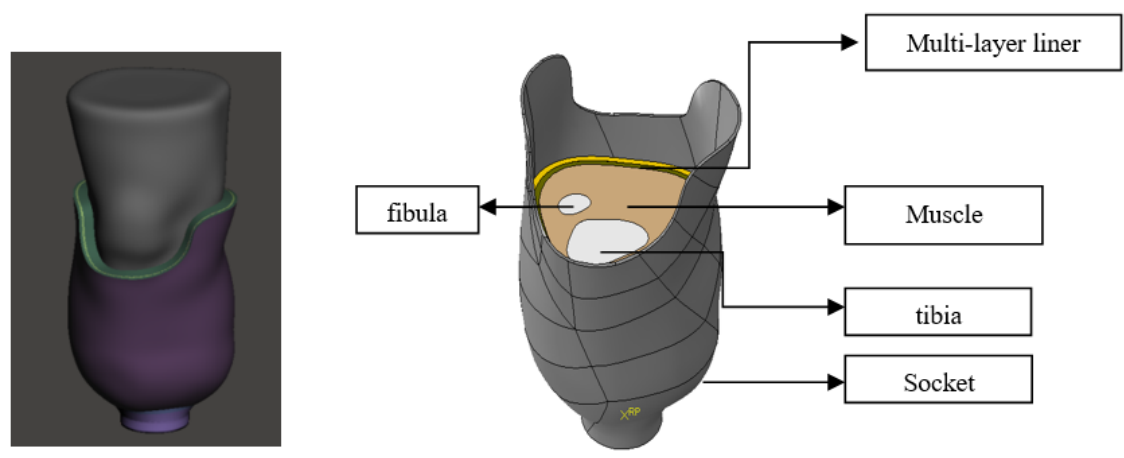

Figure 1: Schematic representation of the STL 3D model and the finite element (EF) model (bone, soft tissue, liner, and socket).

The liner was divided into two sections the thickness of each section was $5 \mathrm{~mm}$ as shown in Fig. 2, by giving each section different mechanical properties, it is possible to simulate different formations of the multi-layer liners as shown in Tab. 1.

\section{Mechanical properties}

The material properties of the tibia bone, soft tissue, and socket were assumed to be linearly elastic, homogeneous, and isotropic. The bone was assigned with Young's modulus of $10 \mathrm{GPa}$ and Poisson's ratio 0.3 [6], Young's modulus of the soft tissue was $200 \mathrm{kPa}$, and Poisson's ratio was assumed to be 0.49 [6], the socket was assigned with Young's modulus of 1.5Gpa and Poisson's ratio 0.3 [8]. 


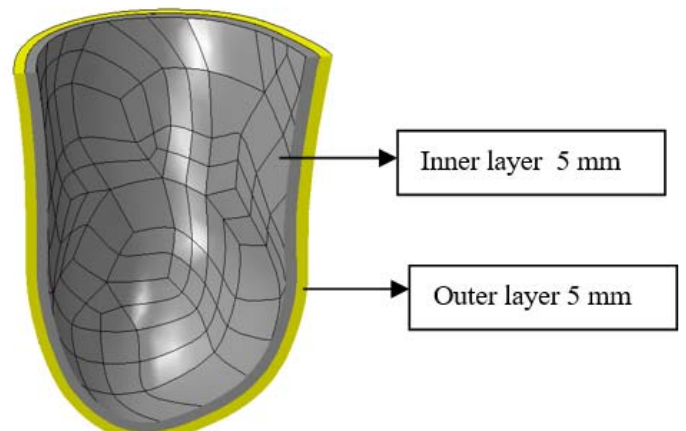

Figure 2: Schematic representation of prosthetic liner (EF).

\begin{tabular}{|c|c|c|}
\hline Liner & Inner layer & Outer layer \\
\hline Liner(a) & Flexible polyurethane foam & $\begin{array}{c}\text { polyurethane-shape memory polymer } \\
\text { foam }\end{array}$ \\
\hline Liner(b) & $\begin{array}{c}\text { polyurethane-shape memory polymer } \\
\text { foam }\end{array}$ & Flexible polyurethane foam \\
\hline Liner $(c)$ & Flexible polyurethane foam & Natural rubber latex foam \\
\hline Liner $(d)$ & Natural rubber latex foam & Flexible polyurethane foam \\
\hline Liner (e) & Natural rubber latex foam & $\begin{array}{l}\text { polyurethane-shape memory polymer } \\
\text { foam }\end{array}$ \\
\hline Liner $(\mathrm{f})$ & $\begin{array}{c}\text { polyurethane-shape memory polymer } \\
\text { foam }\end{array}$ & Natural rubber latex foam \\
\hline
\end{tabular}

Table 1: The different configurations of all six multi-layer foam linersStudied.

\begin{tabular}{ccc}
\hline Structure & Young's modulus & Poisson's ratio \\
bone & $10 \mathrm{GPa}$ & 0.3 \\
soft tissue & $200 \mathrm{kPa}$ & 0.49 \\
socket & $1.5 \mathrm{GPa}$ & 0.3 \\
\hline
\end{tabular}

Table 2: Details material properties for the (FE) model.

For the liners the foam the flexible polyurethane foam, polyurethane-shape memory polymer foam, and natural rubber latex foam were assigned as hyper-elastic materials, the open-cell flexible polyurethane foam was assigned with hyperelastic Ogden's model $\mu 1=7.27 \mathrm{MPa}, \alpha 1=1.63, \mu 2=-7.2 \mathrm{MPa}, \alpha 2=1.63, \mu 3=8.5 \mathrm{E}-4 \mathrm{Mpa}, \alpha 3=45.75$ [9].

Fig. 3 shows the mechanical properties of polyurethane shape memory polymer foam [10] and natural rubber latex foam [11] used.

\section{Boundary and loading conditions}

The interfaces between the bone and soft tissue were tied, the physical contact between the stump and the liner was represented by using surface-to-surface contact. The coefficient of friction (COF) between the liner and soft tissue was assumed to be $0.5[3,6,8]$.

A static vertical load equivalent to the half body weight [12] $(350 \mathrm{~N})$ was applied on top of the tibial bone, the distal end of the socket was fixed. 


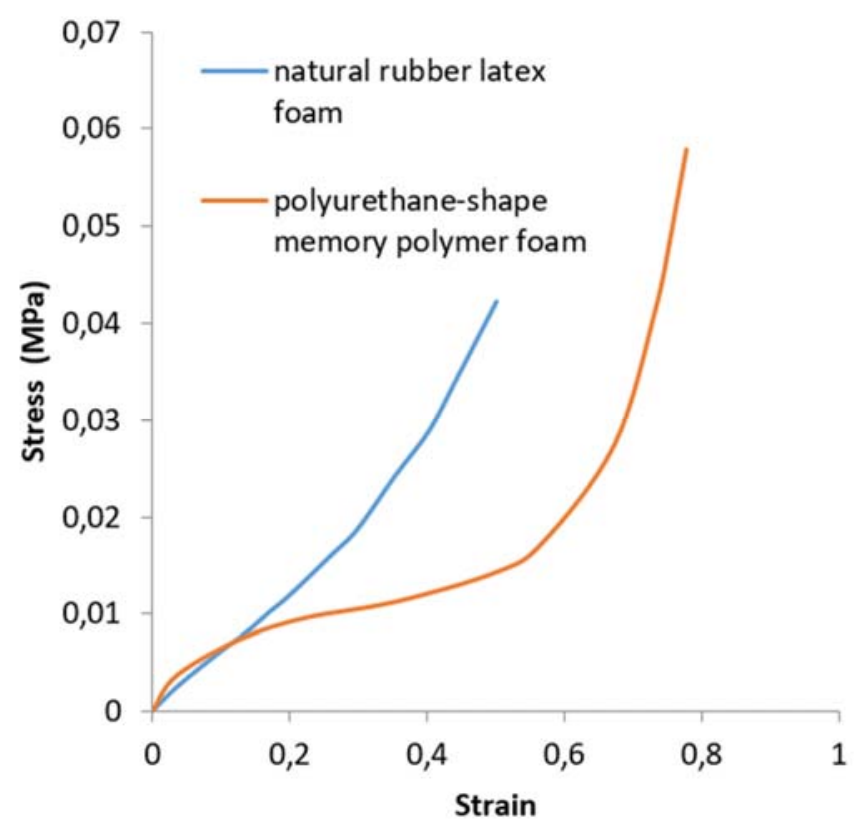

Figure 3: Compressive stress strain relationship of natural rubber latex foam and polyurethane-shape memory polymer foam.
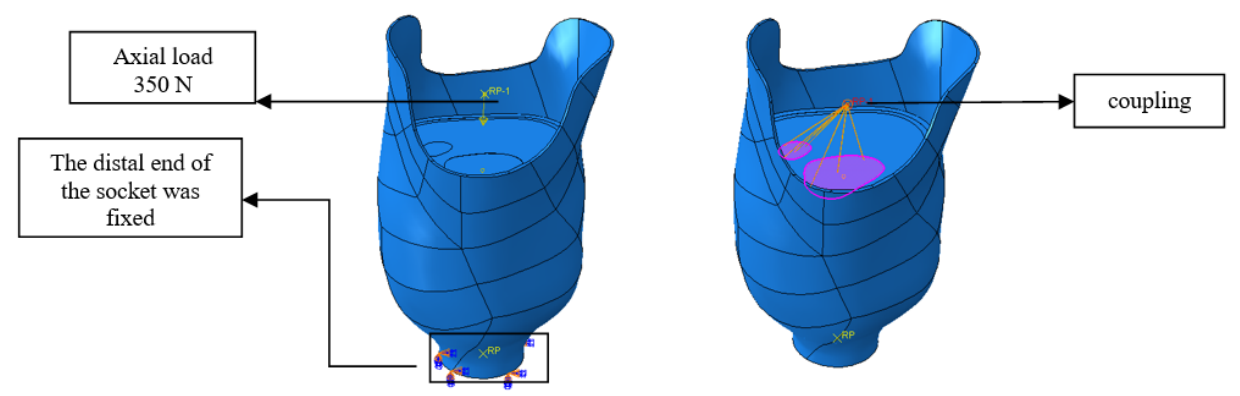

Figure 4: Schematic representation of load and boundary conditions.

Mesh

Tetrahedral meshes for all components (bone, soft tissue, socket, and liner), was chosen tetrahedral meshes are generally preferred over hexahedral meshes for free-formed complex geometries as the former is computationally more efficient [13].

\begin{tabular}{ccc}
\hline Structure & Elements number & Element type \\
Bone & 32539 & C3D4 \\
Soft tissue & 6411 & C3D4 \\
Socket & 26185 & C3D4 \\
Liner & 33257 & C3D4 \\
\hline
\end{tabular}

Table 3: Mesh properties used 

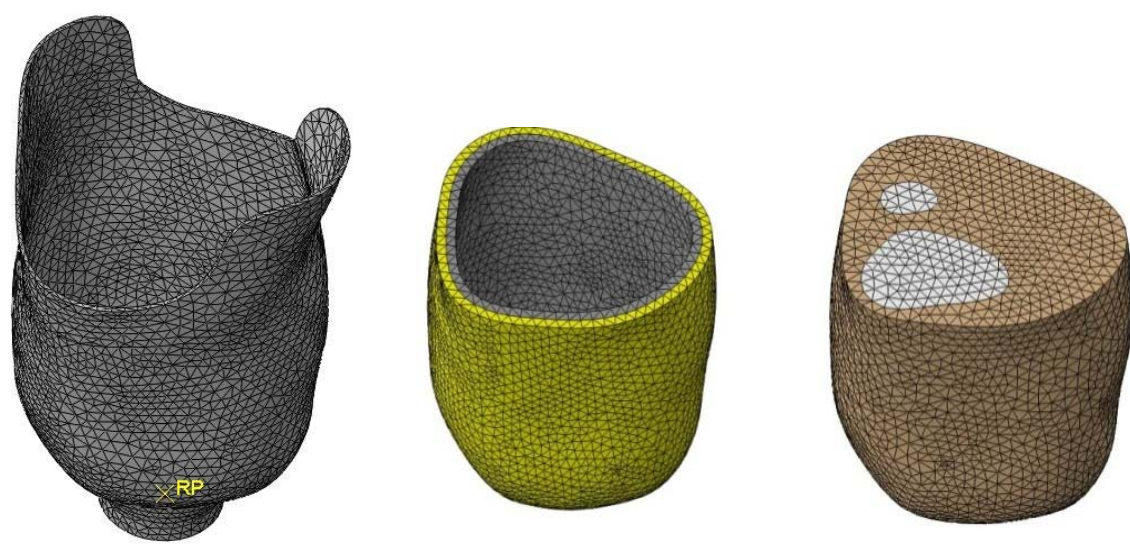

Figure 5: Mesh of the analyzed (FE) model.

\section{RESULTS}

$\mathrm{T}$

is section outlines the stresses obtained at the interference between the trans-tibial prosthesis and the stump due to the body weight application, this reflects the residual limb reaction with all six cases of multi-layer prosthetic foam liner shown in the Tab.1.

The results based on the peak contact pressure and peak longitudinal shear stress at the stump interface. The computed contact pressure and the shear stress will help determine which liner produces the least pressure on the stump-prosthetic interface. The vertical displacement recorded in the liners was used to compare their weight-bearing capacity in every case. Fig. 6 shows the distributions of contact pressure at the stump-prosthetic interface for all liners cases, the patellar tendon area, and the region under the amputated tibia bone were recorded the highest pressure distributions. The highest contact pressure recorded in the stump between all cases was in the liner (f) up to $52 \mathrm{kPa}$, the lows contact pressure between all cases was in the cases of liners (a) and (c) up to $31 \mathrm{kPa}$ and $30 \mathrm{kPa}$ respectively as shown in the Fig. 8.
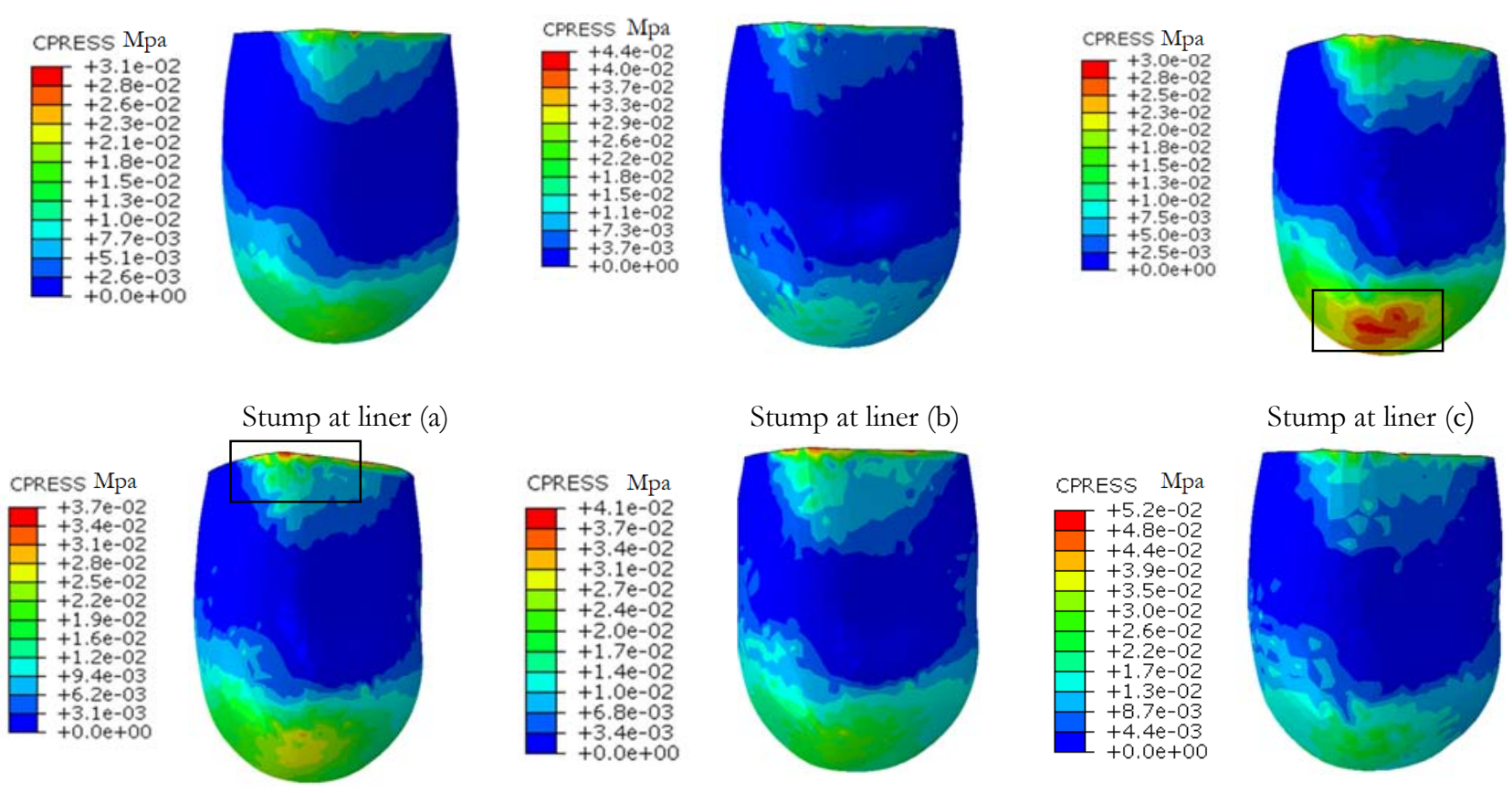

Stump at liner (b)
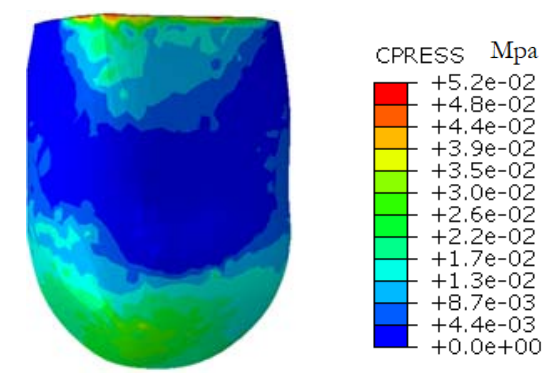

Stump at liner (c)

Stump at liner (d)

Stump at liner (e)

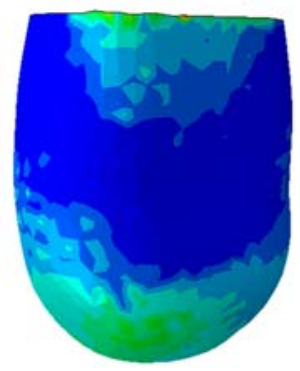

Stump at liner $(f)$

Figure 6: Distributions of contact pressure at the stump interface for all six types of multi-layerliners. 
Fig. 7 shows the distributions of longitudinal shear stress at the stump-prosthetic interface for all liners cases, the patellar tendon area, and the region under the amputated tibia bone were recorded the highest longitudinal shear stress distributions. The highest longitudinal shear stresses recorded in the stump between all cases was in the cases of liners (b), (e), and (f) up to 22,20 and $26 \mathrm{Kpa}$ respectively, the lows longitudinal shear stress between all cases was in the cases of liners (a) and (c)up to15 Kpa as shown in the Fig. 8.
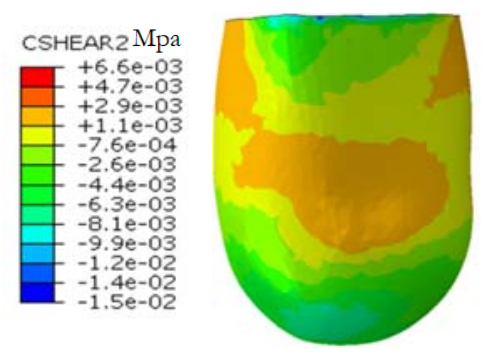

Stump at liner (a)

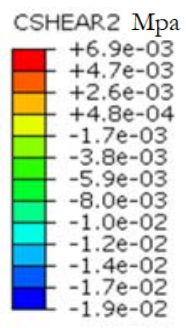

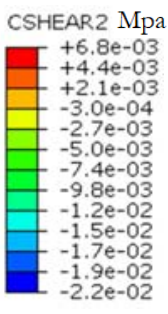

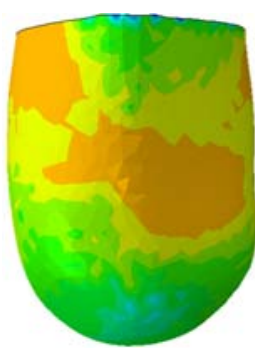

Stump at liner (b)

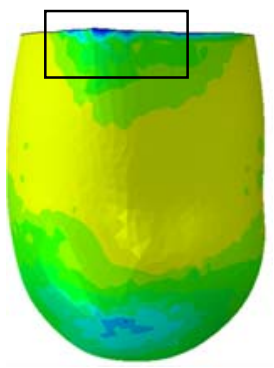

Stump at liner (d)
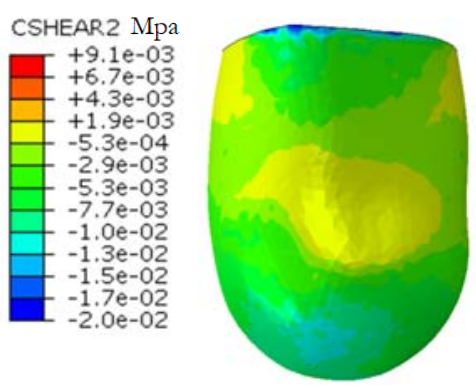

Stump at liner (e)

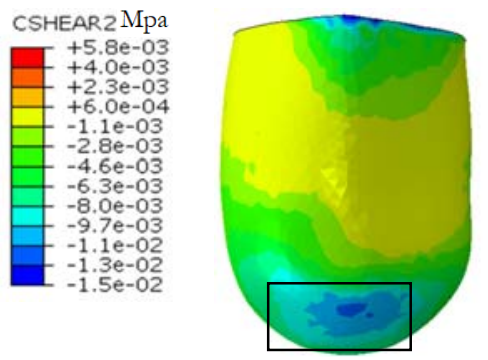

Stump at liner (c)

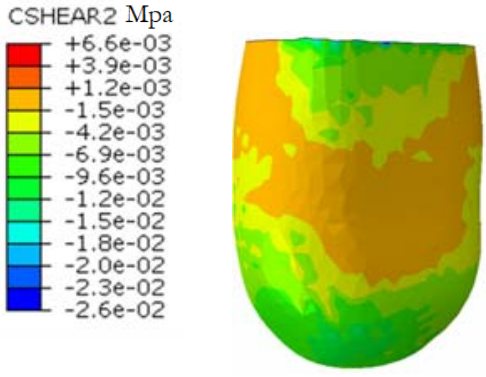

Stump at liner (f)

Figure 7: Distributions of longitudinal shear stress at the stump interface for all six types of multi-layerliners.

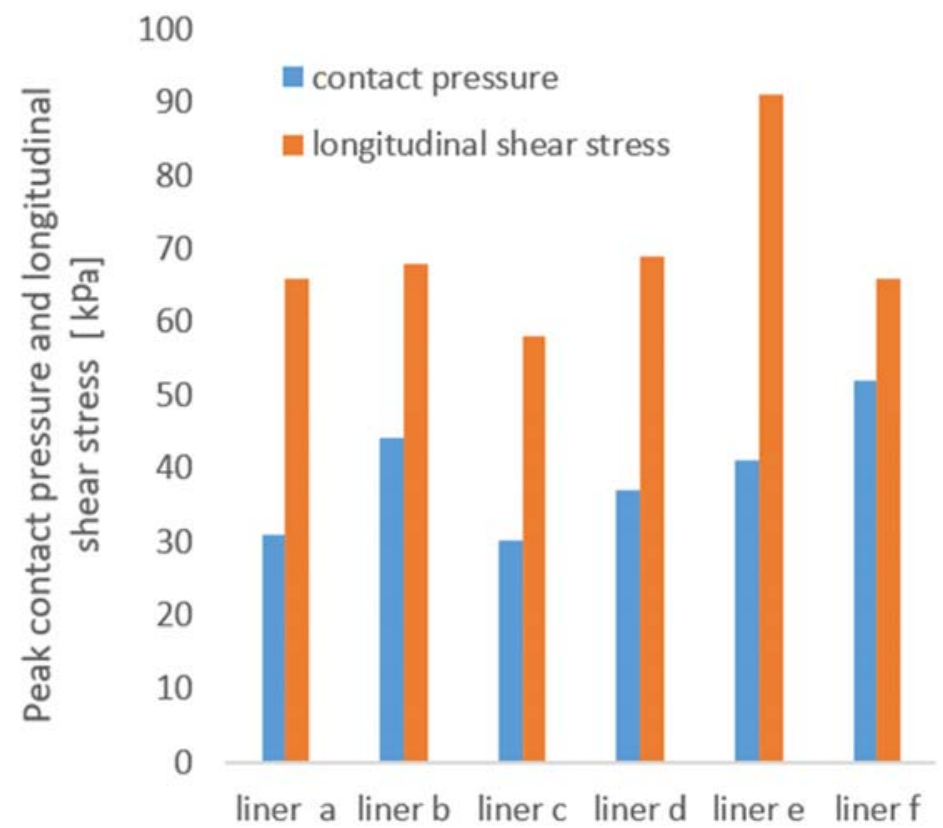

Figure 8: Peak contact pressure and longitudinal shear stress at the stump-liner interface for all multi-layer liners cases.

The distributions of displacement in all six cases of multi-layer prosthetic foam liner allow knowing the capacity of these liners to support the patient's weight. Fig. 9 shows the distributions of vertical displacement at all liners cases, the highest vertical displacement distributions in the liners was located in the area below the tibia end, the highest displacement 
between all cases was recorded in the liner (a) up to $9.2 \mathrm{~mm}$, the lows displacement between all cases was in the cases of liners (e) and (f) up to 5.5 and $5.4 \mathrm{~mm}$ respectively.

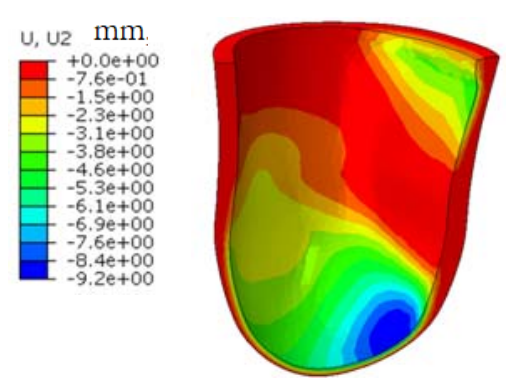

Liner (a)

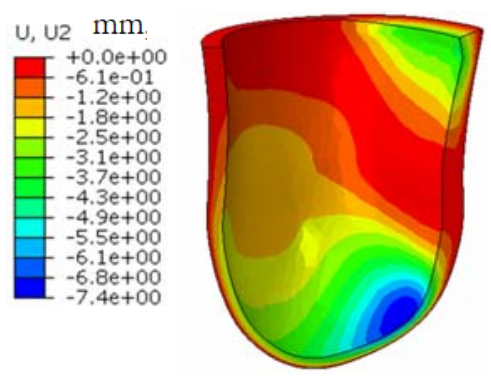

Liner (d)

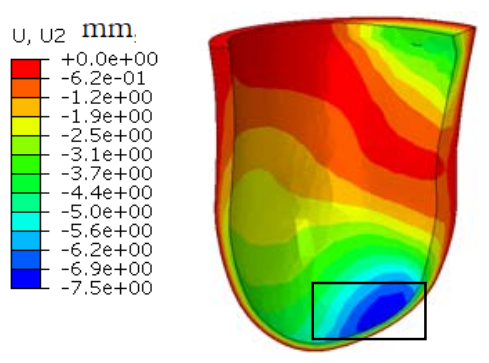

Liner (b)
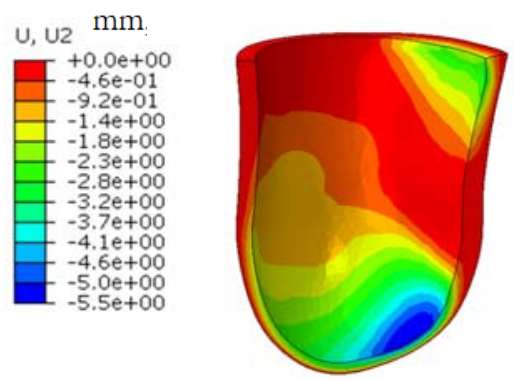

Liner (e)

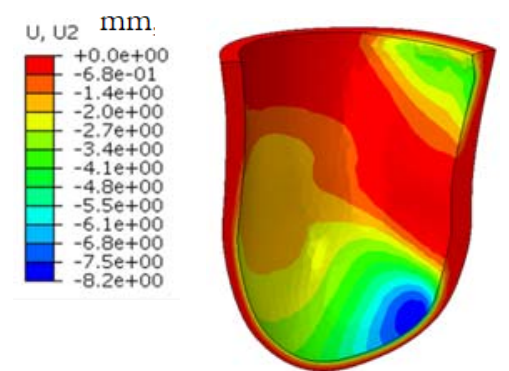

Liner (c)

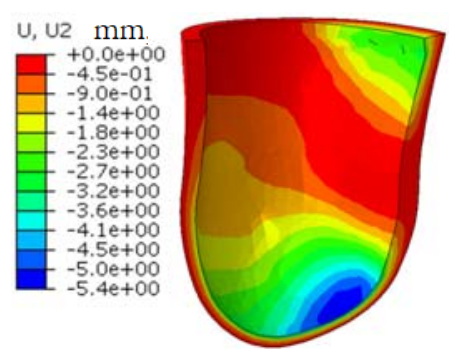

Liner $(\mathrm{f})$

Figure 9: Distribution of displacement along the load axis (U2) in all liners cases.

\section{CONCLUSION}

$\mathrm{I}$ $\mathrm{n}$ this study, A 3D nonlinear FE model was established to predict contact pressure and longitudinal shear stress at the stump interface, a static force equivalent to the half-body weight was applied at the knee joint during a two-leg stance.

The effects of multi-layer prosthetic foam liner materials inertia during analysis were estimated by comparing the results of the stresses at the stump-prosthetic interface.

Based on the study of Cagle et al [7] it can be said that the stresses recorded on the prosthesis interface in all cases of multi-layer foam liners in this study were very suitable for patient's comfort, the peak contact pressure values did not exceed in the highest case $52 \mathrm{kpa}$, and $25 \mathrm{kpa}$ for the longitudinal shear stress.

Through this simulation, the multi-layer prosthetic foam liners were showed High efficiency in reducing the stress at the stump-prosthetic interface. However, some cases of multi-layer prosthetic foam liners did not show adequate support for the patient's weight, it's recorded large displacement values (liner (a) and liner(c)).

The multi-layer foam liners that have achieved the best balance between low stress values at the stump-prosthetic interface and weight bearing capacity were the liners (b) and (d).

\section{REFERENCES}

[1] Ziegler-Graham, K., MacKenzie, E. J., Ephraim, P. L., Travison, T. G., and Brookmeyer, R. (2008), "Estimating the prevalence of limb loss in the United States: 2005 to 2050", Archives of physical medicine and rehabilitation, 89(3), 422-429. DOI: 10.1016/j.apmr.2007.11.005

[2] Radcliffe, C. W. (1955). Functional considerations in the fitting of above-knee prostheses. Biomechanics Laboratory, University of California, 2(1), pp. $35-60$. 
[3] Lin, C. C., Chang, C. H., Wu, C. L., Chung, K. C. and Liao, I. C. (2004). Effects of liner stiffness for trans-tibial prosthesis: a finite element contact model, Medical engineering and physics, 26(1), pp. 1-9.

DOI: $10.1016 /$ S1350-4533(03)00127-9.

[4] Zachariah, S. G. and Sanders, J. E. (2000). Finite element estimates of interface stress in the trans-tibial prosthesis using gap elements are different from those using automated contact, Journal of Biomechanics, 33(7), pp. 895-899. DOI: 10.1016/S0021-9290(00)00022-1.

[5] Ballit, A., Mougharbel, I., Ghaziri, H. and Dao, T. T. (2020). Fast soft tissue deformation and stump-socket interaction toward a computer-aided design system for lower limb prostheses, Irbm, 41(5), pp. 276-285.

DOI: $10.1016 / j . i r b m .2020 .02 .003$.

[6] Jia, X., Zhang, M. and Lee, W. C. (2004). Load transfer mechanics between trans-tibial prosthetic socket and residual limb_dynamic effects, Journal of biomechanics, 37(9), pp. 1371-1377. DOI: 10.1016/j.jbiomech.2003.12.024.

[7] Cagle, J. C., Reinhall, P. G., Allyn, K. J., McLean, J., Hinrichs, P., Hafner, B. J. and Sanders, J. E. (2018). A finite element model to assess transtibial prosthetic sockets with elastomeric liners, Medical and biological engineering and computing, pp. 56(7), 1227-1240. DOI: 10.1007/s11517-017-1758-z.

[8] Lee, W. C., Zhang, M., Jia, X. and Cheung, J. T. (2004). Finite element modeling of the contact interface between trans-tibial residual limb and prosthetic socket, Medical engineering and physics, 26(8), pp. 655-662. DOI: 10.1016/j.medengphy.2004.04.010.

[9] Ju, M. L., Jmal, H., Dupuis, R. and Aubry, E. (2014). A comparison among Polynomial model, Reduced polynomial model and Ogden model for polyurethane foam, In Advanced Materials Research, 856, pp. 169-173.

DOI: $10.4028 / w w w . s c i e n t i f i c . n e t / A M R .856 .169$

[10] Tobushi, H., Okumura, K., Endo, M. and Hayashi, S. (2001). Thermomechanical properties of polyurethane-shape memory polymer foam, Journal of intelligent material systems and structures, 12(4), pp. 283-287. DOI: 10.1106/FNSX-AP9V-QP1R-NMWV.

[11] Karim, A. F. A., Ismail, H. and Ariff, Z. M. (2018). Effects of Kenaf Loading and Alkaline Treatment on Properties of Kenaf Filled Natural Rubber Latex Foam, SainsMalaysiana, 47(9), pp. 2163-2169. DOI: $10.17576 /$ jsm-2018-4709-26.

[12] Wu, C. L., Chang, C. H., Hsu, A. T., Lin, C. C., Chen, S. I. and Chang, G. L. (2003). A proposal for the pre-evaluation protocol of below -knee socket design-integration pain tolerance with finite element analysis, Journal of the Chinese Institute of Engineers, 26(6), pp. 853-860. DOI: 10.1080 /02533839.2003.9670840.

[13] Ramos, A. and Simoes, J. A. (2006). Tetrahedral versus hexahedral finite elements in numerical modeling of the proximal femur, Medical engineering and physics, 28(9), pp. 916-924. DOI: 10.1016/j.medengphy.2005.12.006. 